\title{
Optimization of Online Learning with A Combination of Offline Practices in The Post-Pandemic Era
}

\section{Henny Dewi Koeswanti ${ }^{1 *}$}

${ }^{1}$ Fakultas Keguruan dan Ilmu Pendidikan Universitas Kristen Satya Wacana, Salatiga, Indonesia

\section{ART I C L E IN F O}

Article history:

Received March 05, 2021

Revised March 10, 2021

Accepted May 11, 2021

Available online May 25, 2021

Kata Kunci:

Pembelajaran Jarak Jauh,

Daring, Luring

Keywords:

Distance Learning, Online, Offline

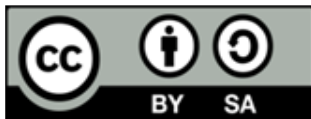

This is an open access article under the CC BY-SA license.

Copyright (ㄷ) 2021 by Author. Published by Universitas Pendidikan Ganesha.

\begin{abstract}
A B S T RAK
Masa Pandemi Covid-19 telah memberikan berbagai dampak di segala aspek kehidupan manusia. Salah satu aspek yang terdampak adalah aspek pendidikan. Pandemi Covid-19 telah menyebabkan terjadinya transformasi metode pembelajaran. Pembelajaran yang semulanya dilaksanakan secara tatap muka bertransformasi menjadi pembelajaran jarak jauh yaitu melalui pembelajaran daring. Transformasi pembelajaran tersebut tentunya memiliki kendala-kendala yang dapat menghambat pelaksanaan proses pembelajaran. Penelitian ini bertujuan untuk mendeskripsikan permasalahan pendidikan yang terjadi selama diberlakukannya pembelajaran daring. Penelitian ini merupakan penelitian kualitatif dengan menggunakan metode deskriptif. Penelitian ini memberikan gambaran tentang pelaksanaan pembelajaran daring serta solusi dan upaya optimalisasi pembelajaran baik secara daring dan luring. Pengumpulan data dilakukan dengan metode studi kepustakaan, yaitu menelaah referensi berupa buku dan artikel ilmiah yang berkaitan dengan topik yang dikaji. Teknik analisis data yang digunakan dalam penelitian ini adalah teknik analisis deskriptif. Hasil penelitian ini menunjukkan bahwa selama masa pandemic Covid-19 dapat dilakukan pembelajaran daring yang dikombinasikan dengan kegiatan luring bagi siswa Pelaksanaan kegiatan tersebut tentunya dengan menerapkan protocol kesehatan yang ketat dan dilaksanakan di rumah masing-masing.
\end{abstract}

\section{A B S T R A C T}

The Covid-19 pandemic has had various impacts on all aspects of human life. One aspect that is affected is the education aspect. The Covid-19 pandemic has led to a transformation of learning methods. Learning that was originally carried out face-to-face has been transformed into distance learning, namely through online learning. The learning transformation certainly has obstacles that can hinder the implementation of the learning process. This study aims to describe educational problems that occur during the implementation of online learning. This research is a qualitative research using descriptive method. This study provides an overview of the implementation of online learning as well as solutions and efforts to optimize learning both online and offline. Data collection was carried out using the literature study method, namely reviewing references in the form of books and scientific articles related to the topic being studied. The data analysis technique used in this research is descriptive analysis technique. The results of this study indicate that during the Covid-19 pandemic, online learning can be carried out combined with offline activities for students. The implementation of these activities is of course by implementing strict health protocols and carried out in their respective homes.

\section{INTRODUCTION}

During the Covid-19 pandemic, learning is required not to be carried out in schools or in the form of PTM (Face-to-Face Learning) (Dong et al., 2020; Sadikin \& Hamidah, 2020). Policies in this pandemic era certainly impose an implementation of learning that must be carried out from each home or PJJ (Distance Learning) (Latip, 2020; Prawiyogi et al., 2020). This condition must be wisely realized that the education and learning sector is the sector that has been hardest hit by the presence of Covid-19 (Wang et al., 2020). Learning must be done with the E-Learning system so that teachers, students, and parents also have to adapt to this new situation. E-Learning is defined as learning that utilizes Information and Communication Technology (ICT) (Halili \& Zainuddin, 2015; Qazi et al., 2021). Online learning has become a demand in the world of education since the last few years (He et al., 2014). The amalgamation of technological resources and innovative educational strategies has transformed the teaching and learning process. Online learning is already needed in learning in the era of the industrial revolution 4.0 (Chick et al., 2020; Pangondian et al., 2019). With an online system, it is hoped that students will be more assisted in their efforts to acquire knowledge and learn without having to meet face to face at school (Mulawarman, 
2020). Previous research has shown that various e-learning and online learning tools are effective for the teaching and learning process (Pangondian et al., 2019). With an online system, it is hoped that students will be more assisted in their efforts to acquire knowledge and learn without having to meet face to face at school (Mulawarman, 2020). Previous research has shown that various e-learning and online learning tools are effective for the teaching and learning process (Astini, 2020; Rosyada et al., 2021). With an online system, it is hoped that students will be more assisted in their efforts to acquire knowledge and learn without having to meet face to face at school (Mulawarman, 2020).

In implementing PJJ requires a set of links between teachers and students (Satrianingrum \& Prasetyo, 2020; Supriyadi, 2020). As a liaison between teachers and students, a connection or network is needed on the device (smartphone) and laptop/PC (Personal Computer). Online learning can be carried out because there are several supporting factors, these supporting factors include smartphones, pulses, quotas and a stable and good internet network (Putria et al., 2020). Smartphones are the main supporting factor in online learning because without smartphones online learning will not be possible. Through the media in the network (online) can expedite learning activities remotely (PJJ). Online learning is also known as virtual-based education or teaching supported by e-learning facilities (Melicherikova \& Busikova, 2012; Qazi et al., 2021). Students can decide about the site and timing of their education so that they are more flexible and avoid physical encounters during the pandemic. Online learning is a program to meet the needs of teachers and students in academic matters during the pandemic and new habit times. Online learning is basically learning that is done virtually through available virtual applications (Syarifudin, 2020). Online learning is considered to be the only medium for delivering material between teachers and students during a pandemic emergency. Online learning is so different from face-to-face learning as usual, online learning emphasizes the accuracy and foresight of students in receiving and processing information presented online (Riyana, 2019). The advantages of carrying out online learning are creating a new learning and teaching atmosphere, online learning will bring a new atmosphere for students and educators, who usually learn face-to-face in class (Sari, 2015). This new atmosphere can foster enthusiasm and interest in students to learn. The shortcomings that occur in online learning are that students find it difficult to focus on learning because the home atmosphere is not conducive. Other than that,

The challenge in online learning is that teachers and students must work together in learning and think about how learning fits into students. For this reason, it is necessary to take strategic steps so that online learning or PJJ runs optimally (Arinto, 2016; Zainal, 2020). One way to maximize PJJ for teachers and students in this post-pandemic recovery era is that PJJ must take advantage of applications on smartphones that can be used as communication tools, such as What'sApp, E-mail, SMS, voice and / or video telephones, and others. Learning media that are interesting and fun for students are able to eliminate boredom in the learning process (Huang \& Mayer, 2019; Widiyono, 2020). However, the applications above are actually not applications that should be used as online learning media, it is an application that is used as a communication tool (Adnan \& Anwar, 2020; Cherubini, 2020). Because of the ease of access provided by the application, some of the teachers use it. For this reason, a survey of teachers or parents or guardians of students was conducted regarding the need for online learning during the pandemic. From the survey results, it can be concluded that there is a need for the use of media or online learning applications as well as training in order to use these application media consistently, focused, and comprehensively. This is because in online learning, it is not just material that is transferred via internet media, it is also not just assignments and social questions that are sent through social media applications. Online learning must be planned, implemented, and evaluated in the same way as learning that occurs in class.

Information Technology (IT) is accelerating human life in a newer era, online learning has changed the way students learn (De Mauro et al., 2018; Kaeophanuek et al., 2019). On the other hand, online learning can be widely accepted if the skills components of teachers, students, and internet facilities are adequate. For users to use online learning efficiently they need skills, such as the ability to recognize material for learning, select and apply learning tactics, observe individual performance, and the ability of knowledge to achieve learning goals (Hung, 2016). The next point that must be of concern in the era of recovery from the pandemic is regarding the optimization of offline competence of students in the post-pandemic recovery era. This optimization can be done by guiding students to be active around the house to find learning materials and practice their learning results online. Therefore, the discourse of online education and learning from home during the pandemic and post-pandemic will definitely involve an online learning system or digital literacy and its application when implemented in real life ((Giatman et al., 2020). This study aims to describe educational problems that occur during the implementation of online learning. This study provides an overview of the implementation of online learning as well as solutions and efforts to optimize learning both online and offline. 


\section{METHOD}

This research is a research that uses a qualitative approach with descriptive analysis method. Qualitative methods are used to understand a phenomenon related to the background of the research subject in depth (Moleong, 2012; Tracy, 2019). The area of this research is in the context of educational activities through learning programs held during the pandemic era in Indonesia. Sources of data that researchers use in this educational research are using a variety of variations that include library data sources of reference review both books and journal articles relevant to this research program. Other than that. The choice of descriptive qualitative use is adjusted to the object of research and the objectives of the research carried out in a natural setting without any intervention from the researcher (Sugiyono, 2015). This research was conducted in several areas in Central Java, including Salatiga, Surakarta, and Sukoharjo. Researchers also observed the learning interactions carried out by teachers and students through online classes through Zoom meetings, google meet, and google classrooms as a means of conducting learning. This is also done as an effort to anticipate and prepare for the next lesson in the post-pandemic era as well as follow-up offline learning that can be done in stages. The strategy that is also used in this research is descriptive analysis. This analysis is carried out by describing and explaining matters relating to the implementation of online learning and its offline application that students and teachers can do in the postpandemic era. The data that supports the research must be verified and studied in depth so that it gets the maximum results so that the follow-up treatment that will be carried out can be in accordance with the needs of teachers and students. Thus this research will provide comprehensive information and clear conclusions related to learning programs in the era of the pandemic and facing the post-pandemic period in order to create ideal learning.

The data that supports the research must be verified and studied in depth so that it gets the maximum results so that the follow-up treatment that will be carried out can be in accordance with the needs of teachers and students. Thus this research will provide comprehensive information and clear conclusions related to learning programs in the era of the pandemic and facing the post-pandemic period in order to create ideal learning. The data that supports the research must be verified and studied in depth so that it gets the maximum results so that the follow-up treatment that will be carried out can be in accordance with the needs of teachers and students. Thus this research will provide comprehensive information and clear conclusions related to learning programs in the era of the pandemic and facing the post-pandemic period in order to create ideal learning.

\section{RESULT AND DISCUSSION}

The existence of the Covid-19 pandemic in the community has had a serious impact in the world of education (Cherubini, 2020; Tang et al., 2021). Almost all parties (teachers, students, parents, and society) find their respective problems in education through the development of skills, knowledge, habits, infrastructure, technology, time, costs, and so on. All parties must participate in thinking actively and creatively to solve all these problems. The challenges of learning policies in the post-pandemic period must be addressed wisely and must be prepared with a combination of online learning management and conventional learning. Online learning definitely requires the support of good and quality information technology infrastructure as well as teachers and students need to understand the principles and methods of good online learning (Dwivedi et al., 2020; Murphy, 2020).

\section{Online Learning Problems}

For some students with various conditions, online learning is not conducive to learning (Cao et al., 2020; Szabo et al., 2020). In fact, children and adolescents feel that there is something that is excluded from public education. Online learning that is held sometimes limits the runag for expression and correspondence. In fact, online learning is held so that it can be of benefit to teachers and students during a pandemic and / or post-pandemic. However, online learning through the implementation of PJJ in fact does not provide satisfaction to teachers and students so there is a need for collaboration in the learning system. Online learning results in a lack of interaction between teachers and students and even between students themselves (Garbe et al., 2020; Hadisi \& Muna, 2015). This lack of interaction can slow down the formation of values in the teaching and learning process. Online learning that is currently being implemented has become a new thing for teachers and students alike. For this reason, the authors believe that in this post-pandemic period it can be done by continuing to carry out online learning through PJJ then some of the material that has been learned can be practiced and implemented at home offline. The problem of online learning by implementing PJJ can be a gap in the learning process. This is likely to be the 
case for many students across the country who experience various learning and educational gaps. Indonesia is a large country with uneven geographic typography and infrastructure, making the gap margin even more visible. This gap is also a manifestation of the impact of infrastructure and technologyrelated support needed to maintain insufficient and equitable virtual learning (Friesen \& Krauth, 2010).

As a good community unit, teachers must realize that currently, the best way to combat the Covid19 outbreak is by implementing social distancing. Specifically, actions to implement health protocols in the form of emergency online learning can reduce the negative impact of the spread of the Covid-19 virus. It also means that this method is meaningful to limit face-to-face class interactions between teachers and students or students and students (Telaumbanua, 2020). To this end, there is actually an important opportunity for the Copenhagen theory of school securitization to inform observation and advocacy in the education sector during this post-pandemic recovery period. What must be understood is that this is a discourse and hope for the author and indeed requires an unexpectedly open discourse under conditions of securitization. As discussed in this article, namely how to carry out education through a combination of online learning and offline learning in a proportional manner after the pandemic. Another phenomenon that has attracted attention in the world of education in the pandemic era is the condition that forces parents of students to become teachers. For example, the phenomenon of students attending elementary school is highly dependent on the role of parents during online learning. There is even a problem about students not being able to attend a lesson if their parents are not at home. Students who are late in turning in assignments are usually forced to wait for parents who are not at home. From this phenomenon, it can be seen that the role of parents is very vital when learning is carried out from home. In addition, problems will arise if parents also do not have mastery of technology, including a systematic online learning system.

Obstacles in online learning programs in this pandemic era are actually closely related to human resources and mastery of information systems and technology as well as the lack of uneven internet facilities. The problem of devices and the availability of internet networks in the territory of Indonesia is a burden for online learning actors (Hidayatullah \& Saud, 2020). Facts in the field indicate that some people do not have devices and cannot access the network internet. Those who live in rural areas or in remote places will find it difficult to get an internet network. People in the lower economic class also find it difficult to get devices or smartphones that can support the learning process. The next problem is that online learning is also expensive. Access to the world of the internet allows students to easily access various learning resources. The consequence is the need for the availability of a strong internet network. During the pandemic, many parties provide subsidies to students for internet quota fees (Asarta, CJ, \& Schmidt, 2020). Subsidies are a consequence of learning from home, so that students can use it for the learning process by buying internet quotas. Many teachers prefer to use applications such as zoom meetings or google meetings to carry out the online learning process. The use of this application for some teachers is easier because it supports virtually. But the complaint from students is that the use of both applications is a waste of paid internet usage. So it requires a large quota of costs for the process of implementing online learning.

\section{Optimization of Online Learning and Offline Practices Based on Prokes}

The post-pandemic situation has transformed educational activities with a combination of online learning and offline implementation. Talking about post-pandemic education is also related to education in the digital era. The pandemic has directly "forced" the government to change various policies regarding education, such as organizing annual evaluations and online learning processes (Murphy, 2020). Online learning is increasingly running as it should, even though there are still problems that accompany the learning. This can be seen from the mastery of teacher competence in utilizing online learning facilities and infrastructure. Ideally, online learning should also be optimized with the lives of teachers and students offline. The diversity of students in Indonesia must be addressed wisely and give authority to students to develop ideas, ideas, field practice, and apply the knowledge obtained online. These efforts must be made considering that the world of education is aggressively re-instilling character values which have now been forgotten to apply. This character value is very important to instill in the souls of students in order to create good conditions for online and applied offline combination learning. So that teachers, students, parents, and society do not just forget about the spirit of the nation's education goals.

Online learning, which was carried out for approximately a year of the Covid-19 pandemic, must have a good impact on education and learning. Teachers, students, parents, and society must work together to create comprehensive and quality learning. As a simple example, junior high school students are being given online learning related to public speeches / lectures. The material must be developed and actualized by asking students to make speeches in front of their parents or relatives when implementing the "At Home Only" program. This simple thing has actually provided insight to all of us that this combination of learning (online and offline) is very necessary and can be implemented gradually and 
continuously for teachers, students, parents, and the community. Another example is that there are institutions around us that use the home visit method, there are also institutions that conduct face-to-face meetings once a week for each group by implementing all health protocols (Taulany, 2020). The corona virus deserves to be watched out for, but it cannot make us fear or drop it so that it can empower us to provide optimal education and learning in accordance with health protocols. There are at least four things that must be done in this effort, namely optimizing planning, organizing, implementing and supervising/ controlling. Optimization of these four things can be done with the Blended Learning learning model. There are also institutions that conduct face-to-face meetings once a week for each group by implementing all health protocols. The corona virus deserves to be watched out for, but it cannot make us fear or drop it so that it can empower us to provide optimal education and learning in accordance with health protocols.

There are at least four things that must be done in this effort, namely optimizing planning, organizing, implementing and supervising / controlling. Optimization of these four things can be done with the Blended Learning learning model. There are also institutions that conduct face-to-face meetings once a week for each group by implementing all health protocols (Hew et al., 2020; Taulany, 2020). The corona virus deserves to be watched out for, but it cannot make us fear or drop it so that it can empower us to provide optimal education and learning in accordance with health protocols. There are at least four things that must be done in this effort, namely optimizing planning, organizing, implementing and supervising / controlling. Optimization of these four things can be done with the Blended Learning learning model. but it is not allowed to make us afraid or drop us so that we can develop education and learning that is optimal and in accordance with health protocols. There are at least four things that must be done in this effort, namely optimizing planning, organizing, implementing and supervising / controlling. Optimization of these four things can be done with the Blended Learning learning model. but it is not allowed to make us afraid or drop us so that we can develop education and learning that is optimal and in accordance with health protocols. There are at least four things that must be done in this effort, namely optimizing planning, organizing, implementing and supervising / controlling. Optimization of these four things can be done with the Blended Learning learning model.

Blended learning is an effort to implement learning in the pandemic era because this learning is able to integrate face-to-face (offline) and online teaching (Graham, 2013). Blended learning can be widely adopted at all levels of education because it can be implemented properly and correctly. Blended learning is able to provide an ease of learning that combines various ways of delivery, teaching models, and learning styles, introducing various media choices for dialogue between the facilitator and the person being taught (Norberg et al., 2011). Blended learning provides an opportunity to organize learning that is supported by an effective combination of the different ways of delivery, teaching methods and learning styles found in open communication. Blended learning is an option that can be made in the current corona pandemic. This refers to the characteristics of the Blended learning program which can mix and match various kinds of learning concepts and strategies. In the implementation of learning through blended learning, the teacher can provide actualization of basic scientific concepts that are applied and explained offline to then be applied logically and comprehensively offline. As an example, Elementary school teachers can do a combination of light exercise movement material for their students who are taught online and then can be applied directly by their students at home with the help of parents, peers, or other family members by practicing offline. This is a real example of what can be done to support online schoolbased Blended learning programs and offline practices.

The social interactions that exist in the practice of blended learning, namely the interaction between teachers and students or students, a combination of online learning and offline practice (face to face), a combination of instructional modalities (media distribution), and a combination of instructional methods in learning. The benefit of using e-learning and blended learning in education today is that elearning provides flexibility in choosing the time and place to access lessons (Code et al., 2020). In addition, blended learning can also make learning diversified and meet the learning characteristics of different students. For example, students who are reluctant to discuss in class may be more active in discussing in writing. Distance learning programs (PJJ) will be more effective if they do a combination of online and offline learning. Teachers and students must have the same understanding regarding this combined learning model. On the one hand, students are also asked to maintain health protocols by continuing online PJJ by utilizing internet connection networks and other learning resources or using a microblogging platform model (Basori, 2013). On the other hand, teachers and students must jointly practice the knowledge previously learned in the offline realm by holding limited social interactions. As a follow-up to the program, the teacher can make student worksheet documents (LKPD) that can be shared and filled in as appropriate. Other than that, with offline practice, students can process information and foster a sense of enthusiasm and social sensitivity. Thus, the spirit of educational goals can be maximally 
achieved and aspects of pedagogy, andragogy, and social competence of actors in educational activities can be fulfilled proportionally.

\section{CONCLUSION}

Online learning is organized so that it can be of benefit to teachers and students during a pandemic and / or post-pandemic. It must be recognized that the implementation of educational activities through online learning has various kinds of problems. The challenges regarding learning in the postpandemic period must be addressed wisely and a combination of online learning management and conventional learning must be prepared. Online learning definitely requires the support of good and quality information technology infrastructure as well as teachers and students need to understand the principles and methods of good online learning. In addition, the optimization of online learning can also be done by practicing offline learning in the home environment of each student by implementing standardized health protocols.

\section{REFERENCES}

Adnan, M., \& Anwar, K. (2020). Online Learning amid the COVID-19 Pandemic: Students' Perspectives. Online Submission, 2(1), 45-51. https: //doi.org/10.33902/JPSP.2020261309.

Arinto, P. B. (2016). Issues and challenges in open and distance e-learning: Perspectives from the Philippines. The International Review of Research in Open and Distributed Learning, 17(2). https://doi.org/10.19173/irrodl.v17i2.1913.

Astini, N. K. S. (2020). Pemanfaatan Teknologi Informasi dalam Pembelajaran Tingkat Sekolah Dasar pada Masa Pandemi Covid-19. Lampuhyang, 11(2), 13-25.

Basori. (2013). Pemanfaatan Social Learning Network "Edmodo" dalam Membantu Perkuliahan Teori JPTIK UNS. Jurnal JIPTEK, 6(2). https://doi.org/10.20961/jiptek.v6i2.12562.

Cao, W., Fang, Z., Hou, G., Han, M., Xu, X., Dong, J., \& Zheng, J. (2020). The psychological impact of the COVID-19 epidemic on college students in China. Psychiatry Research, 287. https://doi.org/10.1016/j.psychres.2020.112934.

Cherubini, L. (2020). Education in the Post-Pandemic Era: Indigenous Children and Youth. The International Indigenous Policy Journal, 1-11. https: //doi.org/10.18584/iipj.2020.11.3.10679.

Chick, R. C., Clifton, G. T., Peace, K. M., Propper, B. W., Hale, D. F., Alseidi, A. A., \& Vreeland, T. J. (2020). Using Technology to Maintain the Education of Residents During the COVID-19 Pandemic. Journal of Surgical Education, 77(4), 729-732. https://doi.org/10.1016/j.jsurg.2020.03.018.

Code, J., Ralph, R., \& Forde, K. (2020). Pandemic designs for the future: perspectives of technology education teachers during COVID-19. Information and Learning Sciences. https: //doi.org/10.1108/ILS-04-2020-0112.

De Mauro, A., Greco, M., Grimaldi, M., \& Ritala, P. (2018). Human resources for Big Data professions: A systematic classification of job roles and required skill sets. Information Processing and Management, 54(5), 807-817. https://doi.org/10.1016/j.ipm.2017.05.004.

Dong, C., Cao, S., \& Li, H. (2020). Young children's online learning during COVID-19 pandemic: Chinese parents' beliefs and attitudes. Children and Youth Services Review, 118(August), 105440. https: //doi.org/10.1016/j.childyouth.2020.105440.

Dwivedi, Y. K., Hughes, D. L., Coombs, C., Constantiou, I., Duan, Y., Edwards, J. S., Gupta, B., Lal, B., Misra, S., Prashant, P., Raman, R., Rana, N. P., Sharma, S. K., \& Upadhyay, N. (2020). Impact of COVID-19 pandemic on information management research and practice: Transforming education, work and life. International Journal of Information Management, 55, 102211. https: //doi.org/10.1016/j.ijinfomgt.2020.102211.

Friesen, J., \& Krauth, B. (2010). Sorting, peers, and achievement of Aboriginal students in British Columbia. Canadian Journal of Economics/Revue Canadienne d'économique, 43(4), 1273-1301. https://doi.org/10.1111/j.1540-5982.2010.01614.x.

Garbe, A., Ogurlu, U., Logan, N., \& Cook, P. (2020). Parents' experiences with remote education during COVID-19 school closures. American Journal of Qualitative Research, 4(3), 45-65. https://doi.org/10.29333/ajqr/8471.

Giatman, M., Siswati, S., \& Basri, I. Y. (2020). Online learning quality control in the pandemic Covid-19 era in Indonesia. Journal of Nonformal Education, 6(2), 168-175. https://journal.unnes.ac.id/nju/index.php/jne/article/view/25594.

Graham, C. R. (2013). Emerging practice and research in blended learning. In Handbook of distance 
education (pp. 333-350). Routledge.

Hadisi, L., \& Muna, W. (2015). Pengelolaan Teknologi Informasi dalam Menciptakan Model Inovasi Pembelajaran (E-Learning). Jurnal Al-Ta'dib, 8(1), 117-140. https://doi.org/10.31332/ATDB.V811.396.

Halili, S. H., \& Zainuddin, Z. (2015). Flipping The Classroom: What We Know and What We Don't. Journal of Distance Education and E-Learning, 3(1), 15-22.

He, W., Xu, G., \& Kruck, S. E. (2014). Online IS education for the 21st century. Journal of Information Systems Education, 25(2), 101-106. https://aisel.aisnet.org/jise/vol25/iss2/1/.

Hew, K. F., Jia, C., Gonda, D. E., \& Bai, S. (2020). Transitioning to the "new normal" of learning in unpredictable times: pedagogical practices and learning performance in fully online flipped classrooms. International Journal of Educational Technology in Higher Education, 17(1). https://doi.org/10.1186/s41239-020-00234-x.

Hidayatullah, A., \& Saud, M. (2020). Digital learning from home and the future of post-pandemic education. Proceeding International Webinar on Education 2020, 217-221. http://103.114.35.30/index.php/Pro/article/view/5979.

Huang, X., \& Mayer, R. E. (2019). Adding Self-Efficacy Features to an Online Statistics Lesson. In Journal of Educational Computing Research (Vol. 57, Issue 4). https://doi.org/10.1177/0735633118771085.

Hung, M. L. (2016). Teacher readiness for online learning: Scale development and teacher perceptions. Computers \& Education, 94, 120-133. https://doi.org/10.1016/j.compedu.2015.11.012.

Kaeophanuek, S., Na-Songkhla, J., \& Nilsook, P. (2019). A learning process model to enhance digital literacy using critical inquiry through digital storytelling (CIDST). International Journal of Emerging Technologies in Learning, 14(3), 22-37. https://doi.org/10.3991/ijet.v14i03.8326.

Latip, A. (2020). Peran Literasi Teknologi Informasi dan Komunikasi Pada Pembelajaran Jarak Jauh di Masa Pandemi Covid-19. EduTeach : Jurnal Edukasi Dan Teknologi Pembelajaran, 1(2), 108-116. https://doi.org/10.37859/eduteach.v1i2.1956.

Melicherikova, Z., \& Busikova, A. (2012). Adaptive E-learning - A tool to overcome disadvantages of Elearning. ICETA 2012 - 10th IEEE International Conference on Emerging ELearning Technologies and Applications, 263-266. https://ieeexplore.ieee.org/abstract/document/6418325.

Moleong, L. J. (2012). Metodologi Penelitian Kualitatif. Remaja Rosdakarya.

Mulawarman, W. G. (2020). Persoalan Dosen dan Mahasiswa Masa Pandemik Covid 19: Dari Gagap Teknologi Hingga Mengeluh Boros Paket Data. Prosiding Seminar Nasional Hardiknas, 37-46. http://proceedings.ideaspublishing.co.id/index.php/hardiknas/article/view/6.

Murphy, M. P. (2020). COVID-19 and emergency eLearning: Consequences of the securitization of higher education for post-pandemic pedagogy. Contemporary Security Policy, 1-14. https://doi.org/10.1080/13523260.2020.1761749.

Norberg, A., Dziuban, C. D., \& Moskal, P. D. (2011). A time-based blended learning model. On the Horizon, 19(3), 207-216. https://doi.org/10.1108/10748121111163913.

Pangondian, R. A., Santosa, P. I., \& Nugroho, E. (2019). Faktor-faktor yang mempengaruhi kesuksesan pembelajaran daring dalam revolusi industri 4.0. Seminar Nasional Teknologi Komputer \& Sains (SAINTEKS). http://prosiding.seminar-id.com/index.php/sainteks/article/view/122.

Prawiyogi, A. G., Purwanugraha, A., Fakhry, G., \& Firmansyah, M. (2020). Efektifitas Pembelajaran Jarak Jauh Terhadap Pembelajaran Siswa di SDIT Cendekia Purwakarta. Jurnal Pendidikan Dasar, 11(01), 94-101.

Putria, H., Maula, L. H., \& Uswatun, D. A. (2020). Analisis proses pembelajaran dalam jaringan (daring) masa pandemi covid-19 pada guru sekolah dasar. Jurnal Basicedu, 4(4), 861-870. https://doi.org/10.31004/basicedu.v4i4.460.

Qazi, A., Hardaker, G., Ahmad, I. S., Darwich, M., Maitama, J. Z., \& Dayani, A. (2021). The Role of Information \& Communication Technology in Elearning Environments: A Systematic Review. A. Qazi et Al.: Role of ICT in Elearning Environments: A Systematic Review, 9, 45539-45551. https://doi.org/10.1109/ACCESS.2021.3067042.

Riyana, C. (2019). Produksi Bahan Pembelajaran Berbasis Online. Universitas Terbuka.

Rosyada, M. I., Atmojo, I. R. W., \& Saputri, D. Y. (2021). Dampak implementasi pembelajaran dalam jaringan (daring) mengenai kualitas pembelajaran ipa di sekolah dasar pada masa pandemi covid19. In Didaktika Dwija Indria (Vol. 9, Issue 4). https://doi.org/10.20961/DDI.V9I4.49180.

Sadikin, A., \& Hamidah, A. (2020). Pembelajaran Daring di Tengah Wabah Covid-19. Biodik, 6(2), 109-119. https://doi.org/10.22437/bio.v6i2.9759.

Sari, P. (2015). Memotivasi Belajar dengan Mengguna.kan E-Learning. Jurnal Ummul Quro, 6(2), 20-35. http://ejournal.kopertais4.or.id/index.php/qura/issue/view/531.

Satrianingrum, A. P., \& Prasetyo, I. (2020). Persepsi Guru Dampak Pandemi Covid-19 terhadap 
Pelaksanaan Pembelajaran Daring di PAUD. Jurnal Obsesi : Jurnal Pendidikan Anak Usia Dini, 5(1), 633. https://doi.org/10.31004/obsesi.v5i1.574.

Sugiyono. (2015). Metode Penelitian Pendidikan pendekatan Kuantitatif, Kualitatif dan R\&D. Alfabeta, Bandung.

Supriyadi. (2020). Pengaruh kemandirian dan dukungan orang tua pada PJJ terhadap prestasi belajar di masa pandemi covid-19. Jurnal Inovasi Pendidikan, 4(2), 56-69. https://doi.org/10.37012/jipmht.v4i2.434.

Syarifudin, A. S. (2020). Impelementasi pembelajaran daring untuk meningkatkan mutu pendidikan sebagai dampak diterapkannya social distancing. Jurnal Pendidikan Bahasa Dan Sastra Indonesia Metalingua, 5(1), 31-34. https://doi.org/10.21107/metalingua.v5i1.7072.

Szabo, T., Richling, S., Embry, D. D., Biglan, A., \& Wilson, K. G. (2020). From helpless to hero: Promoting values-based behavior and positive family interaction in the midst of COVID-19. Behavior Analysis in Practice. https://doi.org/10.1007/s40617-020-00431-0.

Tang, Y. M., Chen, P. C., Law, K. M. Y., Wu, C. H., Lau, Y., Guan, J., He, D., \& Ho, G. T. S. (2021). Comparative analysis of Student's live online learning readiness during the coronavirus (COVID-19) pandemic in the higher education sector. Computers \& Education, 168(March), 104211. https://doi.org/10.1016/j.compedu.2021.104211.

Taulany, H. (2020). Manajemen Proses Pembelajaran Pendidikan Anak Usia Dini Pasca Pandemi Covid-19. Prosiding Seminar Nasional Pascasarjana (PROSNAMPAS), 150-157. https://proceeding.unnes.ac.id/index.php/snpasca/article/download/565/484.

Telaumbanua, D. (2020). Urgensi Pembentukan Aturan Terkait Pencegahan Covid-19 Di Indonesia. QALAMUNA: Jurnal Pendidikan, Sosial, Dan Agama, 12(1), 59-70. https://doi.org/10.37680/qalamuna.v12i01.290.

Tracy, S. J. (2019). Qualitative research methods: Collecting evidence, crafting analysis, communicating impact. John Wiley \& Sons.

Wang, G., Zhang, Y., Zhao, J., Zhang, J., \& Jiang, F. (2020). Mitigate the effects of home confinement on children during the COVID-19 outbreak. The Lancet, 395(10228), 945-947. https://doi.org/10.1016/S0140-6736(20)30547-X.

Widiyono, A. (2020). Efektifitas Perkuliahan Daring (Online) pada Mahasiswa PGSD di Saat Pandemi Covid 19. Jurnal Pendidikan, 8(2), 169-177. https://doi.org/10.36232/pendidikan.v8i2.458.

Zainal, N. H. (2020). Tantangan Kebijakan Pembelajaran Jarak Jauh Di Era Pandemi COVID 19. Jurnal Pencerahan, 14(2), 133-151. http://www.jurnalpencerahan.org/index.php/jp/article/view/31. 